\title{
Comparative wood anatomy of root and stem of Citharexylum myrianthum (Verbenaceae)
}

Anatomia comparada da madeira de raiz e caule em Citharexylum myrianthum (Verbenaceae)

\author{
Carmen Regina Marcati ${ }^{1,4}$, Leandro Roberto Longo ${ }^{1}$, Alex Wiedenhoeft ${ }^{2}$ \& Claudia Franca Barros $^{3}$
}

\begin{abstract}
Root and stem wood anatomy of $C$. myrianthum (Verbenaceae) from a semideciduous seasonal forest in Botucatu municipality (22 $52^{\prime} 20^{\prime \prime}$ S and 48²6'37’W), São Paulo state, Brazil, were studied. Growth increments demarcated by semi-ring porosity and marginal bands of axial parenchyma were observed in the wood of both root and stem. Many qualitative features were the same in both root and stem: fine helical thickenings, and simple and multiple perforation plates in vessel elements; large quantities of axial parenchyma in the growth rings, grading from marginal bands and confluent forming irregular bands in earlywood to lozenge aliform in latewood; axial parenchyma cells forked, and varied wall projections and undulations; septate fibres; forked and diverse fibre endings. Quantitative features differing between root and stem wood were evaluated using student's t-test, and vessel frequency, vessel element length, vessel diameter, ray height, and vulnerability and mesomorphy indices differed significantly. Root wood had lower frequency of vessels, narrower and longer vessel elements, and taller rays than wood of the stem. The calculated vulnerability and mesomorphy indices indicated that $C$. myrianthum plants are mesomorphic. Roots seem to be more susceptible to water stress than the stem.

Key words: secondary xylem, semideciduous seasonal forest, wood anatomy.

\section{Resumo}

A anatomia da madeira da raiz e do caule de Citharexylum myrianthum (Verbenaceae) que ocorre em uma área de floresta estacional semidecídua próximo à cidade de Botucatu (2252'20”S e 48²6’37'W), estado de São Paulo, Brasil, foi estudada. Camadas de crescimento distintas, demarcadas por anel semi-poroso e faixas marginais de parênquima axial foram observadas em ambos os órgãos. As características qualitativas observadas tanto em raiz quanto em caule foram: espessamentos helicoidais finos e placas de perfuração simples e múltiplas em elementos de vaso; grandes quantidades de parênquima axial nos anéis de crescimento, em faixas marginais a confluente formando faixas irregulares no lenho inicial a aliforme losangular no lenho tardio; células do parênquima axial bifurcadas, com projeções e ondulações na parede; fibras septadas; fibras bifurcadas e com diversas terminações. $\mathrm{Na}$ análise quantitativa comparativa entre raiz e caule foi aplicado teste t-student que mostrou diferenças significativas na frequência e diâmetro de vasos; comprimento dos elementos de vaso; altura dos raios; índices de vulnerabilidade e mesomorfia. A madeira da raiz teve menor frequência de vasos, vasos com menor diâmetro e elementos mais longos, e raios mais altos. Os índices de vulnerabilidade e mesomorfia indicaram que as plantas de C. myrianthum são mesomórficas. As raízes parecem estar mais susceptíveis ao estresse hídrico do que os caules.
\end{abstract}

Palavras-chave: anatomia da madeira, floresta estacional semidecídua, xilema secundário.

\section{Introduction}

Citharexylum myrianthum Cham., a deciduous tree, reaches 8 to $15 \mathrm{~m}$ in height and 20 to $40 \mathrm{~cm}$ in breast height diameter, and has a wide occurrence in Brazilian forest formations (latitude $14^{0} 45^{\prime}-31^{0} 50$ 'S $)$. It occurs in Dense Ombrophilous Forest (Atlantic Rain Forest sensu stricto), semideciduous seasonal forest, riparian areas (Carvalho

\footnotetext{
${ }^{1}$ Universidade Estadual Paulista (UNESP), Faculdade de Ciências Agronômicas (FCA), Depto. Ciência Florestal, R. José Barbosa de Barros 1780, 18610-307, Botucatu, SP, Brazil.

${ }^{2}$ Center for Wood Anatomy Research, Forest Products Laboratory, One Gifford Pinchot Dr, Madison, WI, 53726-2398, USA.

${ }^{3}$ Instituto de Pesquisas Jardim Botânico do Rio de Janeiro, Diretoria de Pesquisas, Lab. Botânica Estrutural, R. Pacheco Leão 915, 22460-040, Rio de Janeiro, RJ, Brazil.

${ }^{4}$ Author for correspondence: carmen@fca.unesp.br
} 
1994), and also in lowland dry tropical forest (Tabarelli 1992). The rapid growth makes $C$. myrianthum an important species for restoration of degraded areas (Sansevero et al. 2009).

General descriptions of wood anatomy of the genus Citharexylum have already been reported by Metcalfe and Chalk (1950). For C. myrianthum, Gomes et al. (1989) studied stem wood anatomy from trees that occurred in eastern part of Paraná state (South Brazil) and it was the first time that radiate perforation plates in vessels were mentioned in this species. Barros et al. (2001) described the wood anatomy of trees from a seasonally flooded forest of the Reserva Biológica de Poço das Antas (Rio de Janeiro state, Southern Brazil). Cambial activity and the seasonal formation of secondary xylem in stems of C. myrianthum occurring at São Paulo State were studied by Marcati (2000) and annual growth rings were observed in the wood. Seasonal presence of acicular calcium oxalate crystals in the cambial zone, with greater abundance in dry than in wet periods, was reported for this species (Marcati 2000; Marcati \& Angyalossy 2005). Across this rich body of work, only stem wood was studied.

Perhaps not surprisingly, given the comparative difficulty of collection specimens, root wood anatomy, in general, has received much less attention than stem wood anatomy (e.g. Gasson $\&$ Cutler 1990). When studied, physiological and anatomical research demonstrated that within a species, root xylem has wider vessels than stem xylem and that root wood is more vulnerable to embolism than stem wood (Alder et al. 1996; Ewers et al. 1997; Machado et al. 1997; Kavanagh et al. 1999; Kolb \& Sperry 1999; McElrone et al. 2004; Psaras \& Sofroniou 2004).

The objectives of this study were to compare root and stem wood anatomy of Citharexylum myrianthum qualitatively and quantitatively and to relate any anatomical differences between the organs to their function and ecological adaptations.

\section{Material and Methods}

Citharexylum myrianthum were collected in a semi-deciduous seasonal forest in the municipality of Botucatu (22052'20'S, 48026'37'W), São Paulo state, south-eastern Brazil. The average annual rainfall is about $1300 \mathrm{~mm}$, with a mean annual temperature of $20^{\circ} \mathrm{C}$. July is the driest and coldest month with mean temperature of $15^{\circ} \mathrm{C}$, and January is the wettest and warmest month with mean temperature of $25^{\circ} \mathrm{C}$. The dry season typically extends from May to September (Fig. 1). Climate data were obtained from the Estação Meteorológica of the Faculdade de Ciências Agronômicas, UNESP, Botucatu, São Paulo State. The Estação Meteorológica was about $11 \mathrm{~km}$ from the study site.

Stem and main root samples from three adult specimens (Tab. 1) were collected at 1.30 $\mathrm{m}$ and $30 \mathrm{~cm}$ distal from root collar, respectively. Wood samples from sapwood were fixed in $70 \%$ ethanol. Transverse, radial and tangential sections $(10-18 \mu \mathrm{m})$ were cut using a sliding microtome. These sections were double stained with $1 \%$ aqueous solution of fuchsin and astra blue (Roeser 1972) and mounted on slides in Entelan ${ }^{\circledR}$ synthetic medium. Some root and stem materials were macerated in a mixture of equal volumes of acetic acid and hydrogen peroxide at $60^{\circ} \mathrm{C}$ (Johansen 1940) for 12 to 24 hours. The material was stained with $1 \%$ aqueous solution of safranin and mounted in glycerin. The presence of calcium oxalate was confirmed, since dilutions with hydrochloric acid $(\mathrm{HCl})$ produced no effect (Chamberlain 1932).

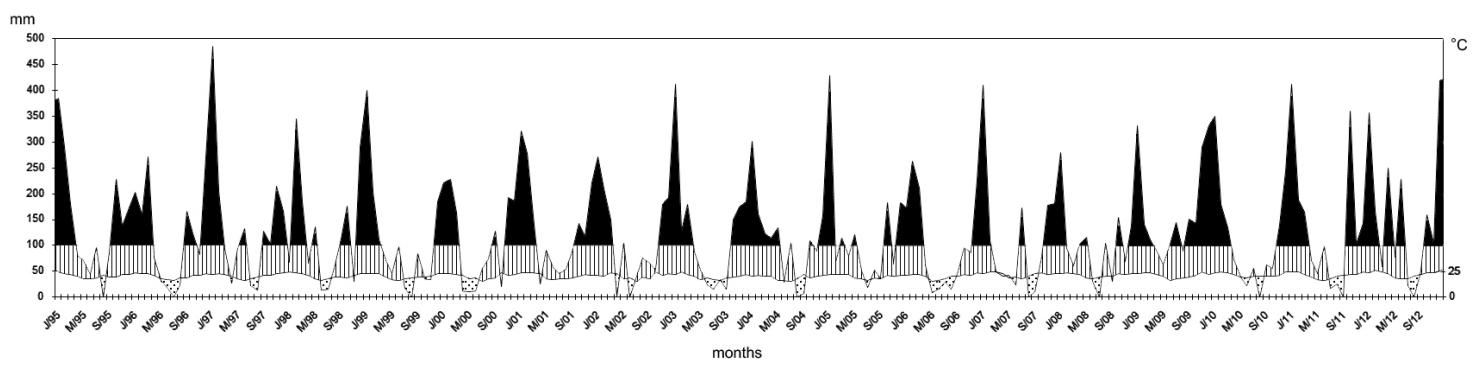

Figure 1 - Climate diagram following Walter (1986), constructed from data obtained at meteorological station located at Faculdade de Ciências Agronômicas (FCA), UNESP, Botucatu, from 1995 to 2012, showing one well demarcated dry season per year. 
Table 1 - Collection data from the Citharexylum myrianthum Cham. studied.

\begin{tabular}{cccc}
\hline $\begin{array}{l}\text { Wood collection } \\
\text { number }\end{array}$ & $\begin{array}{c}\text { DBH } \\
(\mathbf{c m})\end{array}$ & $\begin{array}{c}\text { Height } \\
(\mathbf{m})\end{array}$ & $\begin{array}{c}\text { Root diameter ** } \\
(\mathbf{c m})\end{array}$ \\
\hline BOT $_{\mathrm{w}} 1369$ & 45 & 17 & 12,0 \\
BOT $_{\mathrm{w}} 1370$ & 29 & 18 & 6,0 \\
BOT $_{\mathrm{w}} 1371$ & 59 & 17 & 8,5 \\
\hline
\end{tabular}

* DBH: diameter at breast height $(1.3 \mathrm{~m})$.

** Root diameter: $30 \mathrm{~cm}$ from the base.

Wood descriptions follow the microscopic features definitions of IAWA Committee (1989).

The vouchers and samples of root and stem wood were deposited, respectively, in the Herbarium (BOT) and in the Wood Collection (BOTw) (Tab. 1) of the Departamento de Recursos Naturais, Faculdade de Ciências Agronômicas, UNESP, São Paulo.

Quantitative data were based on 30 individual counts per specimen; the statistical requirements or minimum numbers of measurements were fulfilled: $\mathrm{n}=(\mathrm{t} \text { value })^{2} *$ (sample variance $) /$ (accuracy of $10 \% \times$ sample mean $)^{2}$, following Freese (1967) and Eckblad (1991). The numerical values given in Table 2 are the means accompanied by standard deviation. Wood anatomical parameters were analysed statistically using the Student's t-test and a threshold of $\mathrm{p}<=0.05$ for significance (Zar 1996).

\section{Results}

Qualitative anatomical features of Citharexylum myrianthum did not vary between stem and root wood; differences between the organs were found only in quantitative features (Tab. 2).

Growth rings - distinct, delimited by marginal bands, semi-ring-porous wood (Fig. 2a-b), and slightly distended rays in earlywood, and radially flattened fibers with thick walls in the latewood. In addition, the axial parenchyma pattern varied through the growth ring, with marginal bands and confluent irregular bands in the earlywood, and confluent and lozenge-aliform in latewood (Fig. 2a-b).

Vessels: predominantly solitary $(70-92 \%)$, in multiples of $2(7-24 \%)$ and of 3-6 (0,8-9\%); fine helical thickenings throughout the body of vessel element in both earlywood and latewood

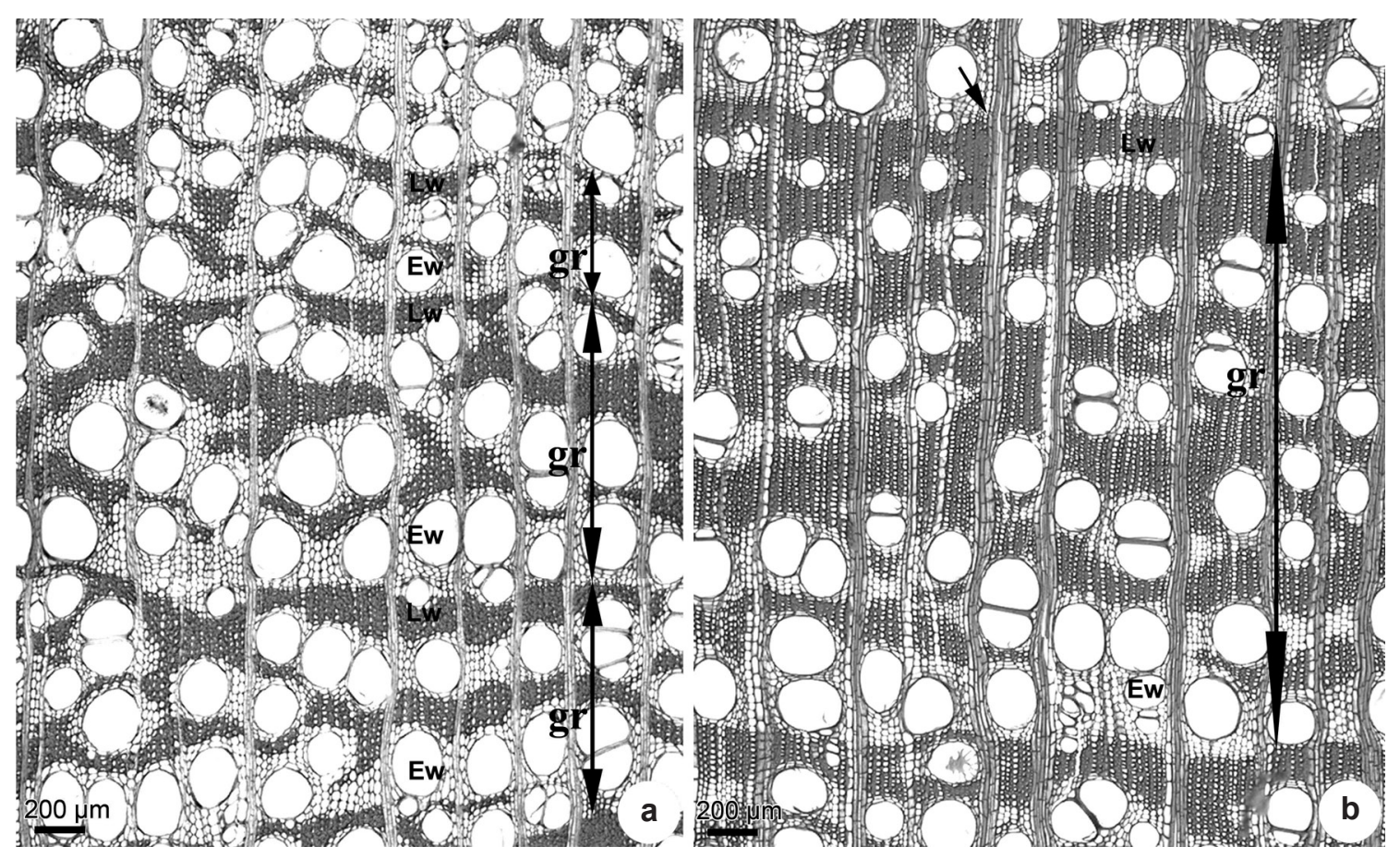

Figure 2 - Transverse sections of Citharexylum myrianthum Cham. wood showing earlywood (Ew) and latewood (Lw) of growth rings (gr) in BOTw1369 stem (a) and in BOTw1369 root (b). Note a slightly distended ray (arrow) in (b). 
Table 2 - Mean and standard deviation of anatomical characteristics of Citharexylum myrianthum Cham. wood, by specimens. $\mathrm{O}=$ organs: $\mathrm{S}=$ stem; $\mathrm{R}=$ root. $\mathrm{L}=$ length in $\mu \mathrm{m}, \mathrm{D}=$ diameter in $\mu \mathrm{m}, \mathrm{F}=$ frequency $\left(\right.$ vessels $\left./ \mathrm{mm}^{2}\right)$ (rays/linear $\mathrm{mm}$ ), $\mathrm{I}=$ index: $\mathrm{v}=$ vulnerability; $\mathrm{m}=$ mesomorphy. $\mathrm{WT}=$ wall thickness of fibres in $\mu \mathrm{m} . \mathrm{W}=$ ray width in cell numbers, $\mathrm{H}=$ rays height in $\mu \mathrm{m}, \mathrm{IV}=$ intervessel pit diameter in $\mu \mathrm{m}, \mathrm{RV}=$ ray-vessel pit diameter in $\mu \mathrm{m}$.

\begin{tabular}{|c|c|c|c|c|c|c|c|}
\hline Specimens & & $\mathrm{BOT}_{w} 1369$ & & $\mathrm{BOT}_{w} 1370$ & & $\mathrm{BOT}_{w} 1371$ & \\
\hline \multirow[t]{2}{*}{$\mathbf{O}$} & & $\mathrm{S}$ & $\mathrm{R}$ & $\mathrm{S}$ & $\mathrm{R}$ & $\mathrm{S}$ & $\mathrm{R}$ \\
\hline & $\mathrm{L}$ & $268.1 \pm 42.7$ & $306.0 \pm 46.0$ & $283.4 \pm 35.0$ & $302.4 \pm 39.3$ & $267.0 \pm 44.1$ & $315.5 \pm 30.5$ \\
\hline \multirow[t]{2}{*}{ Vessels } & $\mathrm{D}$ & $148.6 \pm 27.2$ & $127.1 \pm 31.4$ & $144.8 \pm 47.7$ & $133.0 \pm 43.4$ & $162.7 \pm 38.8$ & $141.1 \pm 40.7$ \\
\hline & $\mathrm{F}$ & $13.1 \pm 2.5$ & $7.9 \pm 2.1$ & $12.0 \pm 2.5$ & $9.4 \pm 3.7$ & $11.0 \pm 3.2$ & $8.1 \pm 2.7$ \\
\hline \multirow{3}{*}{ I } & $\mathrm{v}$ & 11.7 & 17.0 & 12.8 & 14.9 & 14.6 & 18.3 \\
\hline & $\mathrm{m}$ & 3067.1 & 5146.0 & 3500.4 & 4343.4 & 3643.4 & 5613.6 \\
\hline & $\mathrm{L}$ & $1055.1 \pm 299.0$ & $1121.6 \pm 206.9$ & $1060.7 \pm 270.2$ & $1127.9 \pm 204.3$ & $1066.7 \pm 270.0$ & $1111.0 \pm 238.0$ \\
\hline \multirow[t]{3}{*}{ Fibres } & $\mathrm{D}$ & $28.8 \pm 4.4$ & $31.5 \pm 2.8$ & $28.6 \pm 4.3$ & $29.2 \pm 4.6$ & $28.7 \pm 4.7$ & $28.7 \pm 3.8$ \\
\hline & WT & $6.1 \pm 1.0$ & $6.0 \pm 0.9$ & $6.2 \pm 1.1$ & $6.2 \pm 1.2$ & $6.1 \pm 1.2$ & $6.2 \pm 1.1$ \\
\hline & W & $3.7 \pm 0.5$ & $3.8 \pm 0.6$ & $3.8 \pm 0.7$ & $3.7 \pm 0.6$ & $3.9 \pm 0.6$ & $3.9 \pm 0.6$ \\
\hline \multirow[t]{2}{*}{ Rays } & $\mathrm{H}$ & $282.7 \pm 86.0$ & $327.1 \pm 145.2$ & $315.7 \pm 120.5$ & $367.9 \pm 116.8$ & $295.6 \pm 97.0$ & $341.2 \pm 160.1$ \\
\hline & $\mathrm{F}$ & $4.4 \pm 0.9$ & $4.5 \pm 0.7$ & $4.3 \pm 0.9$ & $4.5 \pm 0.9$ & $4.4 \pm 1.0$ & $4.5 \pm 0.8$ \\
\hline \multirow[t]{2}{*}{ Pits } & IV & $3.6 \pm 0.7$ & $4.0 \pm 0.5$ & $3.8 \pm 0.8$ & $3.8 \pm 0.7$ & $3.8 \pm 0.9$ & $3.8 \pm 0.5$ \\
\hline & RV & $3.8 \pm 0.6$ & $3.9 \pm 0.7$ & $3.9 \pm 0.9$ & $3.9 \pm 0.6$ & $4.0 \pm 0.5$ & $3.9 \pm 0.7$ \\
\hline
\end{tabular}

(Fig. 3a); vessel element tails of different shapes in one or both tips; simple perforation plates (Fig. 3b), radiate (Fig. 3d), and foraminate-reticulate perforation plates (Fig. 3c,e), transverse (Fig. $3 \mathrm{c}-\mathrm{e})$ or inclined (Fig. 3a); intervessel pits alternate, circular (Fig. 3a,b); vessel-ray pits similar to intervessel pits in shape and in size. Rays: predominantly multiseriate (Fig. 3f), heterocellular, body ray cells procumbent with one row of upright and/or square marginal cells (Fig. 3g). Axial parenchyma: paratracheal aliform, confluent forming irregular bands, and initial marginal bands (Fig. 2a,b); variable from 3-4 cells per strand mostly, occasionally more than 6 cells per strand; cells forked (Fig. 3i), with projections
(Fig. 3j), and undulations (Fig. 3h). Fibres: thinto thick- walled (Fig. 2a,b); simple to minutely bordered small pits only in radial walls; septate fibres (Fig. 3k) and nonseptate fibres present; fibres with wall interruptions (Fig. 31); forked and with a wide range of tip shapes (Fig. $3 \mathrm{~m}$ o). Mineral inclusions: acicular calcium oxalate crystals in ray parenchyma cells (procumbent, upright and/or square cells).

Statistical analysis - The mean data by organ and the results of the student's t-test are summarized in Tab. 3 and the mean differences between organs are graphically summarized in Fig. 4. Vessel element parameters including length, tangential diameter, and frequency, as 

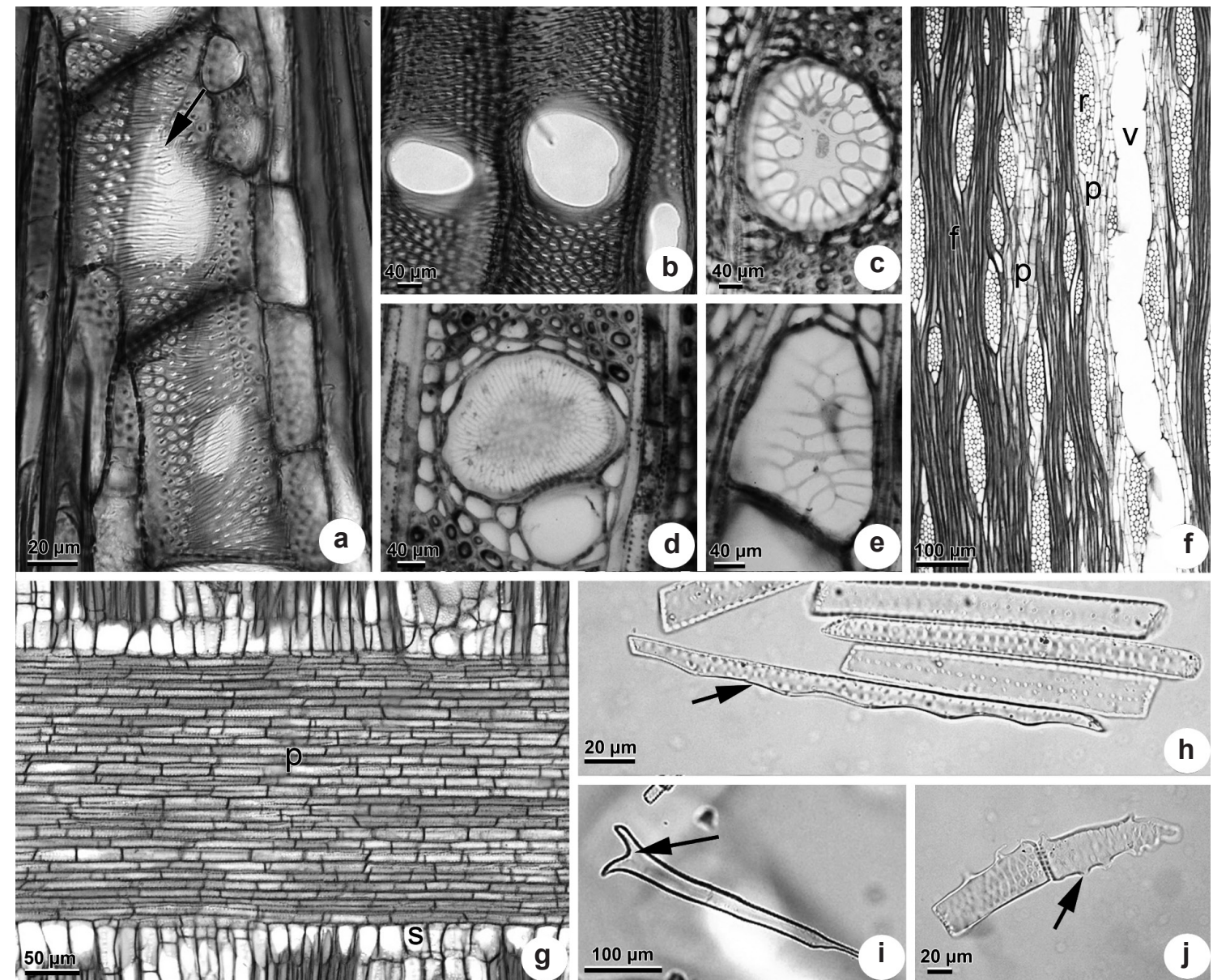

$+2$
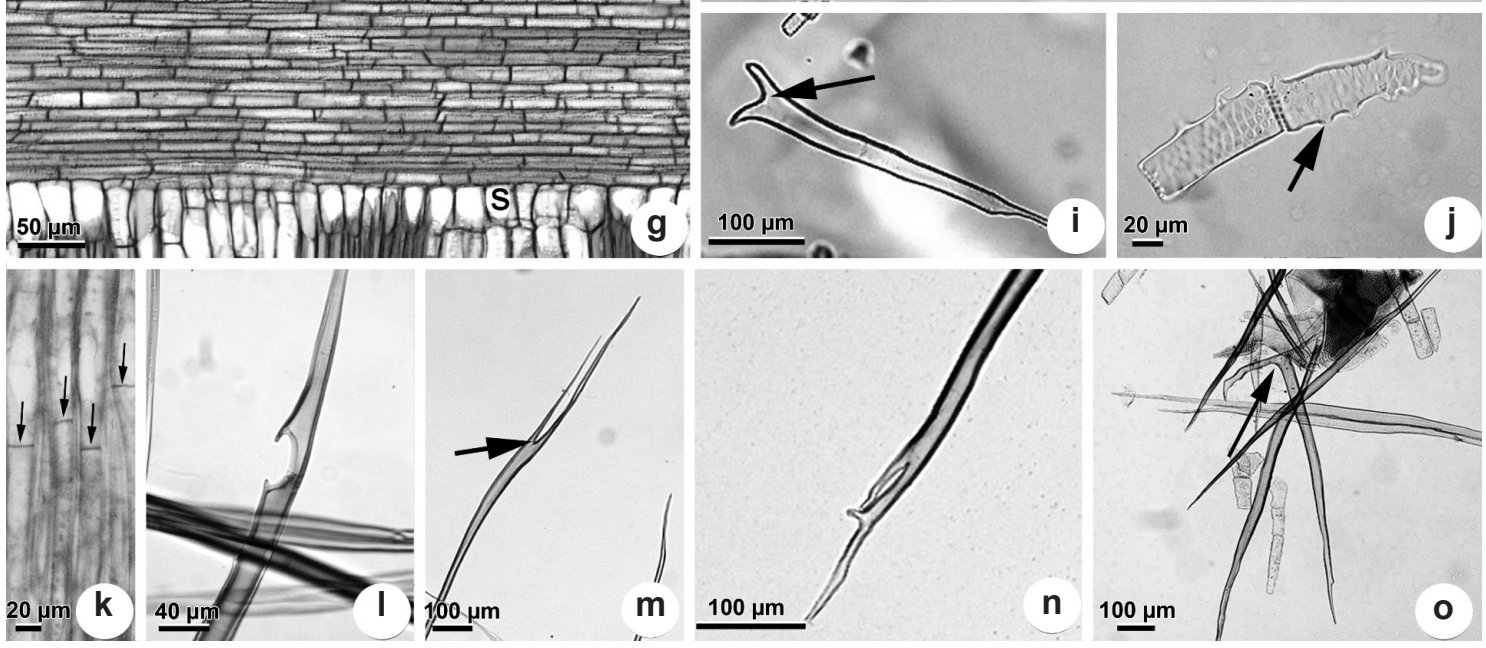

h

Figure 3 - Different aspects of Citharexylum myrianthum Cham. wood - a. fine helical thickenings (arrow) in vessel wall in longitudinal view. Intervessel pitting alternate, circular. b-e. Perforation plates in vessels $-b$. simple in longitudinal radial section; $\mathrm{c}$-e. multiple foraminate-reticulate $(\mathrm{c}, \mathrm{e})$ and radiate (d) in transverse sections. f. Multiseriate rays in longitudinal tangential section.Vessel (v), axial parenchyma (p) and fibres (f) are also showed. g. Heterocellular ray showing body ray cells procumbent (p) with one row of upright and/or square (s) marginal cells in radial section. $\mathrm{h}-\mathrm{j}$. Axial parenchyma cells in macerated wood $-\mathrm{h}$. with undulations (arrow) in the wall; i. forked (arrow); j. with projections (arrow) in the cell wall. k-o. Fibres - k. septate (arrows) in longitudinal view; 1. interruption in the cell wall; m-o. different arrangements of the fibre tip; m. forked (arrow); o. flat tip (arrow).

well as ray height were significantly different between root and stem. Root wood had lower vessel frequency, longer and narrower vessel elements when compared to stem wood.
Root wood had taller rays than stem wood. Vulnerability and mesomorphy indices are significantly different between the two organs (Tab. 3 and Fig. 4). 
Table 3 - Student's t-test between root and stem measurements. * significant at $\mathrm{p}<0.05 . \pm$ standard deviation. L $=$ length in $\mu \mathrm{m}, \mathrm{D}=$ diameter in $\mu \mathrm{m}, \mathrm{F}=$ frequency $\left(\right.$ vessels $\left./ \mathrm{mm}^{2}\right)$ (rays/linear $\left.\mathrm{mm}\right), \mathrm{I}=$ index: $\mathrm{v}=$ vulnerability; $\mathrm{m}$ $=$ mesomorphy. $\mathrm{WT}=$ wall thickness of fibres in $\mu \mathrm{m} . \mathrm{W}=$ ray width in cell numbers, $\mathrm{H}=$ rays height in $\mu \mathrm{m}, \mathrm{IV}=$ intervessel pit diameter in $\mu \mathrm{m}, \mathrm{RV}=$ ray-vessel pit diameter in $\mu \mathrm{m}$.

\begin{tabular}{ccccc}
\hline & & Mean stem & Mean root & F-ratio \\
\hline \multirow{3}{*}{ Vessels } & $\mathrm{L}^{*}$ & $272.87 \pm 41.06^{*}$ & $307.96 \pm 39.10^{*}$ & $1.10^{*}$ \\
& $\mathrm{D}^{*}$ & $152.05 \pm 39.18^{*}$ & $133.73 \pm 39.18^{*}$ & $1.01^{*}$ \\
I & $\mathrm{F}^{*}$ & $12.06 \pm 2.87^{*}$ & $8.26 \pm 2.96^{*}$ & $1.06^{*}$ \\
& $\mathrm{~V}^{*}$ & $13.47 \pm 5.30^{*}$ & $18.15 \pm 9.23^{*}$ & $3.03^{*}$ \\
& $\mathrm{~m}^{*}$ & $3671.13 \pm 1591.13^{*}$ & $5601.17 \pm 2996.87^{*}$ & $1.15^{*}$ \\
& $\mathrm{~L}$ & $1061.11 \pm 277.11$ & $1120.18 \pm 214.63$ & 1.66 \\
Fibres & $\mathrm{D}$ & $28.75 \pm 4.44$ & $29.83 \pm 3.97$ & 1.25 \\
& $\mathrm{WT}$ & $6.153 \pm 1.1129$ & $6.18 \pm 1.06$ & 1.10 \\
& $\mathrm{~W}$ & $3.79 \pm 0.63$ & $3.78 \pm 0.58$ & 1.18 \\
Rays & $\mathrm{H}$ & $298.01 \pm 101.96^{*}$ & $345.42 \pm 141.31^{*}$ & $1.92^{*}$ \\
& $\mathrm{~F}$ & $4.37 \pm 0.93$ & $4.48 \pm 0.81$ & 1.31 \\
& $\mathrm{IV}$ & $3.77 \pm 0.80$ & $3.85 \pm 0.61$ & 1.74 \\
& $\mathrm{RV}$ & $3.90 \pm 0.70$ & $3.88 \pm 0.66$ & 1.13 \\
\hline
\end{tabular}

\section{Discussion}

Our observations of the stem wood of Citharexylum myrianthum are in concordance, in general, with previous descriptions of the genus (Metcalfe \& Chalk 1950; Détienne \& Jacquet 1983) and of the species (Gomes et al. 1989; Marcati 2000; Barros et al. 2001). The inclusion of root wood anatomy in this study broadens the literature on C. myrianthum and allows for within-plant organographic comparisons.

The presence of growth rings in root wood has been demonstrated for a variety of different species in diverse habitats, such as in Styrax (Styracaceae) (Machado et al. 1997), in Clusia criuva (Clusiaceae) (Esemann-Quadros 2001), and in Lippia salviifolia (Verbenaceae) (Goulart \& Marcati 2008). These findings provide counterexamples to the assertions of Ledebenko (1962) and Brown (1971), who suggested that root wood is less likely to form growth rings because of the comparative uniformity of the environmental conditions in the soil. Esemann-Quadros (2001), Machado et al. (1997) and Goulart \& Marcati (2008) suggested that the seasonal soil water availability might be an important factor affecting the formation of growth rings in the wood of roots and stems. We agree with these authors and further suggest that by tracking such soil parameters, a greater appreciation for the variability of the soil environment and its influence on plant development can be gained. The trees studied here grew in a semi-deciduous seasonal forest with a dry season of about 5 months. During the dry season, soil water availability is low (Borchert 1994) and thus the roots experience at least one form of distinct seasonality presumably sufficient to signal distinct growth increment formation in the roots.

Semi-ring porous wood and marginal bands of axial parenchyma delimiting growth rings have already been described by Metcalfe \& Chalk (1950) in Citharexylum, and by Gomes et al. (1989) in C. myrianthum specifically, but only for stem wood. Metcalfe \& Chalk (1950) stated that semi-ring porous wood is a common feature to Verbenaceae and, according to Carlquist (2001), this feature would provide functional advantage to the species as wide earlywood vessels would accommodate larger volumes of water in wet seasons while narrow latewood vessels maximize the resistance to cavitation during the dry season. If this rationale holds true, the presence of semi-ring porosity in the roots suggests that the seasonality of soil water availability may strongly influence root wood vessel diameter.

Combinations of simple and multiple perforation plates in Verbenaceae woody species are 

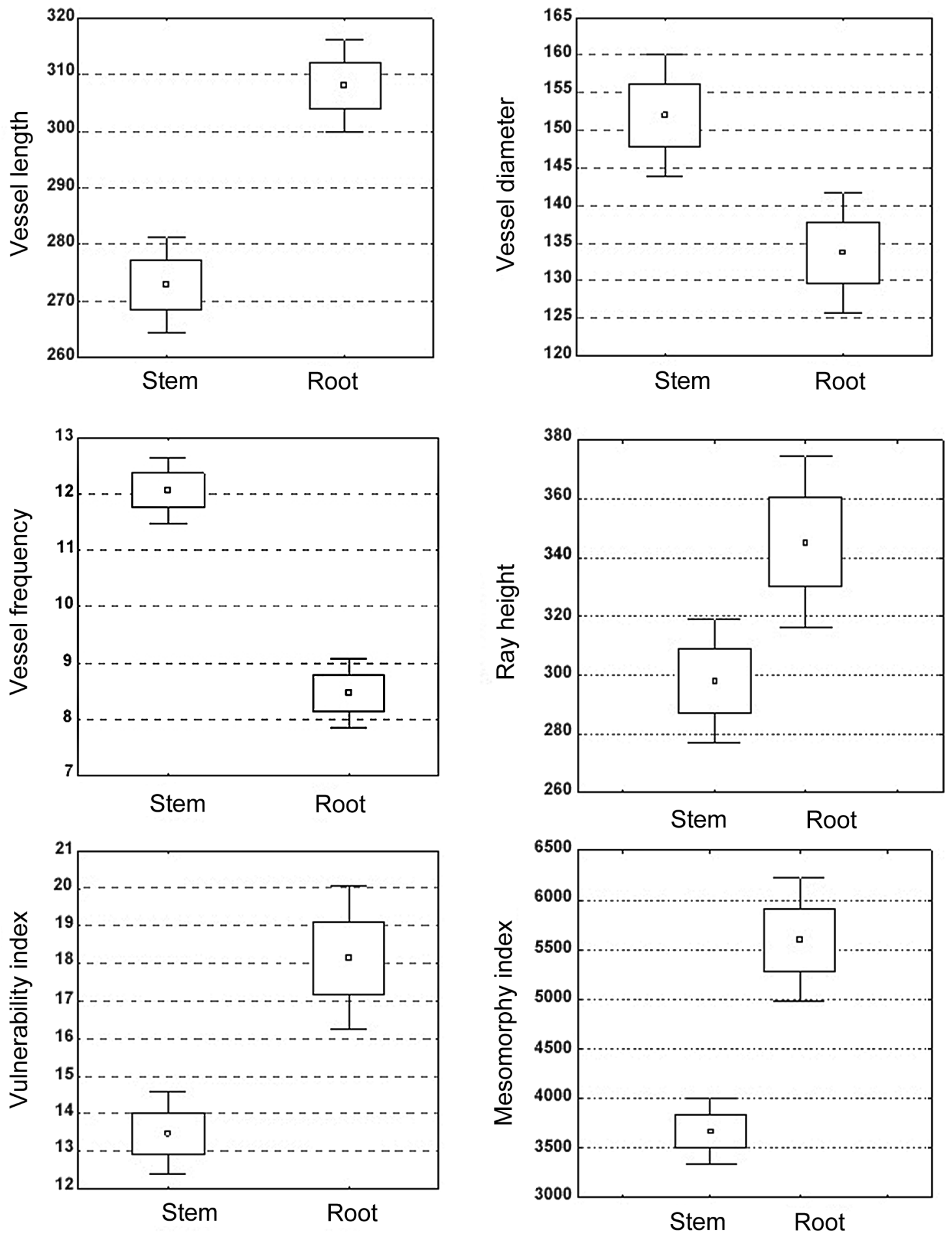

Figure 4 - Box \& Whisker plots of the significant parameters that differ between root and stem according to the Student's t-test $(p=0.05)$. $\square=$ mean, $\square=$ mean \pm standard error, ${ }_{\perp}^{\top}=$ mean \pm 1.96 standard error. 
common and were described in Vitex sp. (Metcalfe \& Chalk 1950), Citharexylum myrianthum (Gomes et al. 1989; Marcati 2000; Barros et al. 2001), Gmelina arborea (Ohtani et al. 1989), and Lippia salviifolia (Goulart \& Marcati 2008). According to Gomes et al. (1989), there are different multiple perforation plates in $C$. myrianthum wood, including radiate and also derivatives from foraminate and reticulate types, and that agrees with what was found in this study. Multiple perforation plates in wood may function in preventing the spread of air embolisms by retaining air bubbles (Wheeler \& Baas 1991). With such a functional interpretation, multiple perforation plates and semiring porous wood would be important contributors to the physiology of this species and its growth in a seasonally dry environment.

Fine helical thickenings in vessel walls were also observed by Gomes et al. (1989) and Barros et al. (2001) to Citharexylum myrianthum. Carlquist (2001) pointed out that the helical thickenings on the vessel walls would increase the contact area between the vessel wall and water column, and might increase the mechanical resistance of the vessel walls. We observed no change in distribution of helical thickenings from earlywood to latewood in C. myrianthum in stem or root, suggesting that an important physiological role related to seasonal water stress is unlikely in this species.

The variation in the axial parenchyma through the increment zone, grading from marginal bands and confluent irregular bands in the earlywood to lozenge aliform in the latewood, and in some places rays slightly distended when crossing the marginal bands of axial parenchyma were described for the first time to this species. Marcati et al. (2006) reported distended rays delimiting growth rings in addition to other markers to some species from cerrado (Piptocarpha rotundifolia (Asteraceae), Annona coriacea and A. crassiflora (Annonaceae)). The distended rays delimiting growth rings might be advantageous in addition to the other growth markers helping the dendrochronologists in the correct distinction of the growth rings limits.

Septate fibres are common in Verbenaceae species, and they were observed in the root and stem wood of Citharexylum myrianthum. As they are living fibres, they could play a role in water and starch storage (Carlquist 2001, 2012), and this might be important in the seasonal environments where the species are growing.
Typically, root vessels are wider than stem vessels (Alder et al. 1996; Ewers et al. 1997; Machado et al. 1997; Kavanagh et al. 1999; Kolb \& Sperry 1999; McElrone et al. 2004; Psaras \& Sofroniou 2004). The opposite was observed in this study in Citharexylum myrianthum, Styrax forest species (Machado et al. 2007) and Leguminosae lianas (Ewers et al. 1997). Christensen-Dalsgaard et al. (2007) associated the smallest vessels and the lowest vessel frequency to parts of the root and stem subjected to the greatest mechanical stresses or strains, observing a trade-off between hydraulic conductivity and wood stiffness. The semi-ring porosity of the root wood combined with larger amounts of axial parenchyma surrounding the vessels may provide functional advantages to the species during the dry season. The axial parenchyma surrounding the narrower vessels may play a role in regulating the osmotic potential of the sap in the dry season, permitting the plants to take up water or refill embolized vessels.

In conclusion, Citharexylum myrianthum root and stem wood were different in quantitative but not qualitative features. The root wood had lower frequency of vessels, narrower and longer vessel elements, a greater abundance of paratracheal axial parenchyma in the latewood, and taller rays than the wood of the stem. The calculated vulnerability and mesomorphy indices (Carlquist 1977) indicated that $C$. myrianthum is mesomorphic, but by comparison, the roots are more susceptible to water stress than the stem. The overall physiognomy of the wood suggests anatomical specialization to seasonally dry environment.

\section{Acknowledgements}

The authors are grateful to Conselho Nacional de Desenvolvimento Científico e Tecnológico - CNPq (Proc. 503425/2005-2), Fundação de Amparo a Pesquisa do Estado de São Paulo FAPESP (Proc. 04/05913-5), and Petrobras for the financial support, and to Dr. Dirk Koedam for his kind and helpful advice in the manuscript.

\section{References}

Alder, N.N.; Sperry, J.S. \& Pockman, W.T. 1996. Root and stem xylem embolism, stomatal conductance and leaf turgor in Acer grandidentatum populations along a soil moisture gradient. Oecologia 105: 293-301.

Barros, C.F.; Callado, C.H.; Marcon, M.L.; Costa, C.G.; Cunha, M.; Lima, H.R.P. \& Marquete, O. 2001. 
Madeiras da Mata Atlântica. Timbers of the Atlantic Rain Forest. Vol. II. Instituto de Pesquisas do Jardim Botânico do Rio de Janeiro, Rio de Janeiro. 100p.

Borchert, R. 1994. Soil and stem water storage determine phenology and distribution of tropical dry forest trees. Ecology 75: 1437-1449.

Brown, C.L. 1971. Secondary growth. In: Zimmermann, M.H. \& Brown, C.L. (eds.). Trees: structure and function. Springer, New York. Pp. 67-123.

Carlquist, S. 1977. Ecological factors in wood evolution: a floristic approach. American Journal of Botany 64: 887-896.

Carlquist, S. 2001. Comparative wood anatomy: systematic, ecological and evolutionary aspects of dicotyledon wood. Springer, Berlin, Heidelberg, 448p.

Carlquist, S. 2012. Fibre dimorphism: cell type diversification as an evolutionary strategy in angiosperm woods. Botanical Journal of the Linnean Society 174: 44-67.

Carvalho, P.E.R. 1994. Espécies florestais brasileiras: recomendações silviculturais, potencialidades e uso da madeira. EMBRAPA - Centro Nacional de Pesquisas em Florestas, Colombo. 640p.

Chamberlain, C.J. 1932. Methods in plant histology. $5^{\text {th }}$ ed. The University of Chicago Press, Chicago. 416p.

Christensen-Dalsgaard, K.K.; Fournier, M.; Ennos, A.R. \& Barfod, A.S. 2007. Changes in vessel anatomy in response to mechanical loading in six species of tropical trees. New Phytologist 176: 610-622.

Détienne, P. \& Jacquet, P. 1983. Atlas d'identification des bois de l'Amanonie et regions voisines. Centre Technique Forestier Tropical, Nogent-sur-Marne, 640p.

Eckblad, J.W. 1991. How many samples should be taken. Bio Science 41: 346-348.

Esau, K. 1967. Plant anatomy. John Wiley \& Sons, New York.

Esemann-Quadros, K. 2001. Anatomia do lenho de Clusia criuva CAMB. (Clusiaceae): órgãos, hábitos e ambientes. Tese de Doutorado. USP, São Paulo. $132 \mathrm{p}$.

Ewers, E.W.; North, G.B. \& Nobel, P.S. 1992. Rootstem junelions of a desert monocotyledon and a dicotyledon: hydraulic consequences under wet conditions and during drought. New Phytologist 121: 377-385.

Ewers, F.W.; Carlton, M.R.; Fisher, J.B.; Kolb, K.J. \& Tyree, M.P. 1997. Vessel diameters in roots versus stems of tropical lianas and other growth forms. IAWA Journal 18: 261-279.

Freese, F. 1967. Elementary statistical methods for foresters. Agriculture Handbook 317. USDA Forest Service, Washington. 87p.

Gasson, P.E. \& Cutler, D. F. 1990. Root anatomy of 17 genera growing in the British Isles. IAWA Bulletin 11: 3-46.
Gomes, A.V.; Teixeira, L.L.; Schaitza, E.G. \& Hofmeister, R.M. 1989. Perforation plates in vessels of Citharexylum myrianthum Cham. (Verbenaceae). IAWA Bulletin 10:27-34.

Goulart, S.L. \& Marcati, C.R. 2008. Anatomia comparada do lenho em raiz e caule de Lippia salviifolia Cham. (Verbenaceae). Revista Brasileira de Botânica 31: 263-275.

IAWA Committee. 1989. List of microscopic features for hardwood identification. IAWA Bulletin 10: 220-332.

Johansen, D. A. 1940. Plant microtechnique. McGrawHill, New York. 523p.

Kavanagh, K.L.; Bond, B.J.; Aitken, S.N., Gartner, B.L. \& Knowe, S. 1999. Shoot and root vulnerability to xylem cavitation in four populations of Douglas-fir seedlings. Tree Physiology 19: 31-37.

Kolb, K.J. \& J.S. Sperry. 1999. Transport constraints on water use by the Great Basin shrub, Artemisia tridentata. Plant Cell Environment 22: 925-935.

Lebedenko, L.A. 1962. Comparative anatomical analysis of the mature wood of roots and stems of some wood plants. Trudy Inst. Lesa I Drevesiny Akad. Nauk SSSR (Sib. Otdel.) 51: 124-134.

Lorenzi, H. 1998. Árvores brasileiras. Vols. 1-2. Instituto Plantarum de Estudos da Flora, São Paulo. 384p.

Machado, S.R.; Angyalossy-Alfonso, V. \& Morretes, B.L. 1997. Comparative wood anatomy of root and stem in Styrax camporum (Styracaceae). IAWA Journal 18: 13-25.

Machado, S.R.; Rodella, R.A.; Angyalossy, V. \& Marcati, C.R. 2007. Structural variations in root ans stem wood of Styrax (Styracaceae) from Brazilian Forest and cerrado IAWA Journal 28: 173-188.

Marcati, C.R. 2000. Sazonalidade cambial em espécies tropicais. Tese de Doutorado. USP, São Paulo. 147p.

Marcati, C.R. \& Angyalossy, V. 2005. Seasonal presence of acicular oxalate crystals in the cambium zone of Citharexylum myrianthum (Verbenaceae). IAWA Journal 26:93-98.

Marcati, C.R.; Oliveira, J.S. \& Machado, S.R. 2006. Growth rings in cerrado woody species: occurrence and anatomical markers. Biota Neotropica (English ed.) 6: 206-320.

McElrone, A.J.; Pockman, W.T.; Martínez-Vilalta, J. \& Jackson, R.B. 2004. Variation in xylem structure and function in stems and roots of trees to $20 \mathrm{~m}$ depth. New Phytologist 163: 507-517.

Metcalfe, C.R. \& Chalk, L. 1950. Anatomy of the dicotyledons. Vols. I-II. Clarendon Press, Oxford. $1500 \mathrm{p}$.

Ohtani, J.; Jing, W.; Fukazawa, K. \& Shao, S.Q. 1989. Multiple perforation plates in Gmelina arborea Roxb. IAWA Bulletin 10:35-41.

Psaras, G.K. \& Sofroniou, I. 2004. Wood anatomy of Capparis spinosa from an ecological perspective. IAWA Journal 20: 419-429. 
Roeser, K.R. 1972. Die nadel der Schwarz KieferMassenprodukt und Kunstwerk der Natur. Mikrokosmos 61: 33-36.

Sansevero, J.B.B.; Prieto, P.V.; Moraes, L.F.D. \& Rodrigues, P.J.F.P. 2011. Natural regeneration in plantations of native trees in lowland Brazilian Atlantic Forest: community structure, diversity, and dispersal syndromes. Restoration Ecology 19: 379-389

Segala-Alves, E. 1997. Anatomia do lenho de algumas famílias arbóreas da flora brasileira, de acordo com diferentes ambientes. Tese de Doutorado. Universidade de São Paulo, São Paulo. 239p.

Sinnott, E.W. \& Bloch, R. 1939. Changes in intercellular relationships during the growth and differentiation of living plant tissues. American Journal of Botany 26: 625-634.

Tabarelli, M. 1992. Flora arbórea da floresta estacional baixo-montana no município de Santa Maria-RS, Brasil. Revista do Instituto Florestal 4: parte 1, (edição especial): 260-268.

Walter, H. 1986. Vegetação e zonas climáticas. EPU, São Paulo. 325p.

Wheeler, E.A. \& Baas, P. 1991. A survey of the fossil record for dicotyledonous wood and its significance for evolutionary and ecological wood anatomy. IAWA Bulletin 12: 275-332.

Zar, J.H. 1996. Biostatistical analysis. $3^{\text {rd }}$ ed. Prentice Hall, New Jersey. 662p. 